Edubiotik: Jurnal Pendidikan, Biologi dan Terapan
ISSN 2528-679X (print), ISSN 2597-9833 (online)
Volume 5, Nomor 02, Tahun 2020, Hal. 123-141
Available online at:
http://ejurnal.budiutomomalang.ac.id/index.php/edubiotik

Research Article

OPEN ACCESS

\title{
Keanekaragaman Odonata di kawasan bendungan lempake, sungai karang mumus dan sungai berambai samarinda
}

\author{
Ratri Arbia Nisita, Nova Hariani*, Sus Trimurti
}

Biologi, Universitas Mulawarman, Kalimantan Timur, Indonesia

Email: rattri.arbia22@gmail.com, ovaaja@gmail.com, sustri82@gmail.com

\begin{tabular}{|c|c|}
\hline Informasi Artikel & ABSTRACT \\
\hline $\begin{array}{l}\text { Submit: } 27-08-2020 \\
\text { Diterima: } 23-12-2020 \\
\text { Dipublikasikan: } 23-12-2020\end{array}$ & $\begin{array}{l}\text { Knowledge of the diversity of dragonflies (Odonata) is very important for river } \\
\text { management which is used for various purposes by humans. This research aims } \\
\text { to determine the diversity of Odonata in the waters of Bendungan Lempake, } \\
\text { Karang Mumus River and Berambai River Samarinda. Sampling was done by } \\
\text { using purposive sampling technique through insect net with transect method along } \\
\text { with the river flow, } 5 \text { times at each location for one month in the morning and } \\
\text { evening. The samples obtained were prepared, stored on triangular paper } \\
\text { containing camphor, and identified using entomological guidelines. Environmental } \\
\text { temperature, humidity, and acidity of the water are calculated using standard } \\
\text { measurement tools. Data is displayed in the form of the number of types and a } \\
\text { description of each type. The results showed that } 1025 \text { individual dragonflies were } \\
\text { found belonging to } 22 \text { species and } 4 \text { families of Odonata. The diversity index value } \\
\text { (H') of dragonflies in the waters of the Bendungan Lempake is } 2.83 \text {, the Karang } \\
\text { Mumus River is } 2.52 \text { and the Berambai River is } 2.53 \text {, which are classified as a } \\
\text { medium category. The conclusion of this research is that the waters of Bendungan } \\
\text { Lempake, Karang Mumus River, and Berambai River are still supporting as habitat } \\
\text { for dragonflies to live and breed. } \\
\text { Key words:; Diversity; dragonflies; Odonata }\end{array}$ \\
\hline Penerbit & ABSTRAK \\
\hline $\begin{array}{l}\text { Program Studi Pendidikan Biologi } \\
\text { IKIP Budi Utomo, Malang, Indonesia }\end{array}$ & $\begin{array}{l}\text { Pengetahuan tentang keanekaragaman capung (Odonata) sangat penting untuk } \\
\text { pengelolaan sungai yang digunakan dalam berbagai kepentingan oleh manusia. } \\
\text { Penelitian ini bertujuan untuk mengetahui keanekaragaman Odonata di kawasan } \\
\text { perairan Bendungan Lempake, Sungai Karang Mumus dan Sungai Berambai } \\
\text { Samarinda. Pengambilan sampel dilakukan dengan teknik purposive sampling } \\
\text { melalui insect net dengan metode transek sepanjang aliran sungai, sebanyak } 5 \\
\text { kali pada masing-masing lokasi selama satu bulan pada pagi hari dan sore hari. } \\
\text { Sampel yang diperoleh dipreparasi, disimpan pada kertas segitiga yang } \\
\text { mengandung kapur barus, dan diidentifikasi menggunakan pedoman entomologi. } \\
\text { Suhu lingkungan, kelembaban udara dan pH air dihitung menggunakan alat ukur } \\
\text { yang terstandarisasi. Data ditampilkan dalam bentuk jumlah jenis dan deskripsi } \\
\text { masing-masing jenis. Hasil penelitian menunjukkan bahwa ditemukan } 1025\end{array}$ \\
\hline 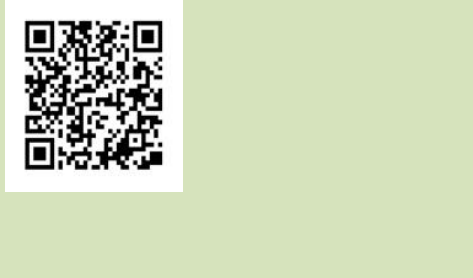 & $\begin{array}{l}\text { individu capung yang tergolong kedalam } 22 \text { spesies dan } 4 \text { famili Odonata. Nilai } \\
\left.\text { indeks keanekaragaman ( } \mathrm{H}^{\prime}\right) \text { capung di kawasan perairan Bendungan Lempake } \\
\text { sebesar } 2,83 \text {, Sungai Karang Mumus sebesar } 2,52 \text { dan Sungai Berambai sebesar } \\
2,53 \text {, yang tergolong kategori sedang. Simpulan penelitian adalah kawasan } \\
\text { perairan Bendungan Lempake, Sungai Karang Mumus dan Sungai Berambai } \\
\text { masih mendukung sebagai habitat capung untuk hidup dan berkembangbiak. } \\
\text { Kata kunci: Capung; keanekaragaman; Odonata }\end{array}$ \\
\hline
\end{tabular}

This Edubiotik : Jurnal Pendidikan, Biologi dan Terapan is licensed under a CC BY-SA (Creative Commons AttributionShareAlike 4.0 International License) 


\section{PENDAHULUAN}

Ordo Odonata ("yang bergigi") merupakan serangga paling kuno dan indah yang pernah hidup di Bumi. Bybee (2018) menjelaskan bahwa Odonata terdiri dari 2 subordo: Anisoptera (yang meliputi semua capung) dan Zygoptera (dikenal dengan capung jarum/damselflies), sedangkan subordo Anisozygoptera (kelompok relik yang diwakili oleh hanya dua spesies yang hidup dan para pakar sudah meninggalkannya). Ordo ini sangat beragam sekitar 5000 spesies, dengan anggota yang mudah diamati (UCMP, 2020). Odonata merupakan salah satu serangga yang merupakan golongan ecosystem services yang dapat dijadikan sebagai bioindikator keadaan suatu lingkungan perairan. Kemampuan Odonata berkembangbiak sepanjang tahun di kawasan perairan tawar yang mempunyai kualitas yang sesuai dengan kebutuhan hidupnya. Odonata identik dengan kawasan perairan tawar karena kelompok ini menghabiskan sebagian besar masa hidupnya sebagai nimfa/naiad yang sangat bergantung pada habitat perairan tawar dan tidak ditemukan satu jenis pun Odonata yang hidup di laut (WfHC, 2020).

Ridwan et al. (2013) menjelaskan bahwa peraian sebagai suatu bentuk ekosistem dapat dibagi menjadi 2 kelompok besar yaitu perairan yang alami (perairan yang terjadi secara alami, contoh sungai, danau, rawa dan lain-lain) dan perairan buatan (perairan yang dibuat oleh manusia untuk keperluan hidupnya, contoh bendungan, waduk, kanal dan lain-lain). Kota Samarinda memiliki kawasan tipe perairan yang beragam, mulai dari yang alami hingga buatan, salah satu contoh kawasan perairan buatan adalah bendungan Lempake, kemudian untuk kawasan perairan alami contohnya adalah sungai Karang Mumus dan sungai Berambai. Bendungan Lempake dan sungai Karang Mumus merupakan kawasan perairan yang di sekitarnya terdapat pemukiman penduduk dan merupakan perairan tawar yang umum digunakan penduduk sebagai sumber utama air dalam kehidupan sehari-hari, sedangkan sungai Berambai merupakan sungai yang belum banyak tersentuh aktifitas manusia karena tidak berada di kawasan pemukiman, namun wilayah di sekitar sungai Berambai merupakan destinasi wisata alam oleh penduduk (Portal Resmi Pemerintah Kota Samarinda, 2012; Muriyani dan Susetiawan, 2002; Wahyuni, 2017).

Indikator biologis merupakan penampakan utuh dari sifat mahluk hidup yang bereaksi (respons) secara langsung dan relatif cepat terhadap adanya perubahan kualitas, kuantitas dan kondisi ekosistem atau sistem lingkungan lahan perairan. Makroinvertebrata merupakan salah satu bioindikator perairan contohnya adalah larva capung. Keberadaan larva capung di suatu perairan akan sangat menentukan keanekaragaman dari capung yang ada di sekitar perairan tersebut (Tjokrokusumo, 2006). Kondisi perairan tawar dibeberapa lokasi di Samarinda yang berbeda dapat diketahui dari gambaran nilai indeks keanekaragaman kelompok hewan yang ada di habitat tersebut, salah satunya keanekaragaman Odonata. Penelitian tentang keragaman Odonata diberbagai kawasan perairan tawar bendungan Lempake, sungai Karang Mumus, dan sungai Berambai, sampai saat ini belum pernah dilakukan. Penelitian yang pernah dilakukan di kawasan tersebut masih terbatas hanya mengenai faktor kondisi ikan. Berdasarkan uraian di atas maka sangat penting untuk mengetahui kondisi lingkungan di tiga kawasan perairan tersebut masih bisa mendukung kelangsungan hidup Odonata atau tidak. Oleh karena itu perlu dilakukan penelitian yang bertujuan untuk mengetahui keanekaragaman Odonata di kawasan perairan Bendungan Lempake, sungai Karang Mumus dan sungai Berambai, Samarinda untuk mengetahui kondisi perairan tersebut.

\section{METODE PENELITIAN}

Penelitian ini adalah penelitian eksplorasi yang dilakukan pada bulan Juli s.d Agustus 2018, koleksi sampel Odonata dilakukan menggunakan insect net dengan metode transek sepanjang 100 
meter di kedua sisi sungai pada tiga titik yaitu hulu, tengah dan hilir selama satu bulan. Penelitian dilakukan di tiga kawasan perairan yang berbeda yaitu di sungai Karang Mumus, Bendungan Lempake dan sungai Berambai, kemudian identifikasi dilakukan di Laboratorium.

Pengambilan sampel di lapangan dilakukan sebanyak 5 kali pada masing-masing lokasi selama satu bulan pada pagi hari pukul 08.00 sampai 11.00 WITA dan sore hari pada pukul 15.00 sampai 17.00 WITA. Pemilihan waktu penelitian berdasarkan waktu aktifnya capung, sehingga diharapkan ditemukan jenis capung yang beragam. Teknik yang digunakan dalam pengambilan sampel adalah purposive sampling pada lokasi yang telah ditentukan dengan menggunakan insect net. Faktor abiotik pada masing-masing lokasi dicatat setiap kali melakukan pengamatan dan pengambilan sampel. Suhu lingkungan, kelembaban udara dan $\mathrm{pH}$ air dihitung menggunakan slyng thermometer. Semua Odonata yang tertangkap ditekan bagian thoraknya kemudian dimasukkan ke dalam kertas papilot. Setelah itu sampel yang didapat dibawa ke laboratorium untuk diidentifikasi menggunakan Borror et al., (2008); Feriwibisono, (2011); Gullan and Cranston (2010); Kalkman and Dingemanse (2008); Munroe (2012); Moore (2001); Morse (2009); Wakhid et al. (2014).

Analisis data yang digunakan untuk menghitung indeks keanekaragaman dan distribusi Odonata menggunakan indeks Shannon-Wiener (Odum, 2005), rumus yang digunakan adalah:

Keterangan:

$$
H^{\prime}=-\sum(\mathrm{Pi} \ln \mathrm{Pi})
$$

$\mathrm{H}^{\prime} \quad$ : Indeks Keanekaragaman jenis

$\mathrm{Pi} \quad: \mathrm{ni} / \mathrm{N}$

$\mathrm{Ni} \quad$ : Jumlah individu jenis ke-1

$\mathrm{N} \quad$ : Jumlah individu semua jenis

$\left(\mathrm{H}^{\prime}\right) \leq 1$ : keanekaragaman rendah; $1<\mathrm{H}^{\prime}<3$ : Keanekaragaman sedang; $\mathrm{H}^{\prime} \geq 3$ : keanekaragaman tinggi

Nilai kemerataan jenis menunjukan tingkat kemerataan keanekaragaman individu antar jenis dihitung menggunakan Indeks evenness (Odum, 2005), rumus yang digunakan adalah:

Keterangan:

$$
\mathrm{E}^{\prime}=\frac{H^{\prime}}{\operatorname{Hmax}}
$$

E : Indeks kemerataan

$H^{\prime} \quad$ : Indeks Keanekaragaman Shannon-Wiener

$\mathrm{H}$ max : Indeks Keanekaragaman maksimum $=\ln \mathrm{S}$, dimana $\mathrm{S}$ : jumlah taksa di dalam komunitas.

Odum (2005) menjelaskan bahwa indeks dominansi merupakan jumlah tiap arti/nilai spesies dalam hubungannya terhadap komunitas sebagai keseluruhan yang dirumuskan dengan:

$$
\underset{i=1}{D_{i}}=\sum(n i / N)^{2}
$$

Keterangan:

D : : Indeks dominansi

ni : Jumlah individu

$\mathrm{N} \quad$ : Total jumlah individu keseluruhan

Nilai kesamaan jenis dihitung menggunakan Indeks kesamaan Jaccard (Magurran, 1998), yang dirumuskan dengan:

$$
\mathrm{SJ}=\frac{a}{(a+b+c)}
$$

Keterangan:

$$
\begin{array}{ll}
\text { SJ } & \text { : Indeks Kesamaan Jaccard } \\
\text { a } & \text { : Jumlah jenis yang terdapat dalam komunitas A dan B } \\
\text { b } & \text { : Jumlah jenis yang terdapat dalam komunitas B saja } \\
\text { c } & \text { : Jumlah jenis yang terdapat dalam komunitas A saja }
\end{array}
$$




\section{HASIL PENELITIAN DAN PEMBAHASAN}

Berdasarkan hasil penelitian diperoleh sebanyak 22 spesies Odonata (capung). Spesies Odonata yang didapatkan dapat dilihat pada Tabel 1.

Tabel 1. Kelimpahan Odonata (Capung) di Kawasan Perairan Bendungan Lempake, Sungai Karang Mumus dan Sungai Berambai

\begin{tabular}{|c|c|c|c|c|}
\hline \multirow{2}{*}{ No } & \multirow{2}{*}{ Nama Takson } & \multicolumn{3}{|c|}{ Jumlah Individu } \\
\hline & & SKM & $B L$ & SB \\
\hline \multicolumn{5}{|c|}{ Subordo Anisoptera } \\
\hline \multirow{3}{*}{1} & & A. Famili Gomphidae & \multirow{3}{*}{-} & \multirow{3}{*}{11} \\
\hline & Ictinogomphus decorates & - & & \\
\hline & & B. Famili Libellulidae & & \\
\hline 2 & Acisoma panorpoides & 3 & 40 & - \\
\hline 3 & Brachydiplax chalybea & 11 & 18 & - \\
\hline 4 & Cratilla lineata & - & - & 14 \\
\hline 5 & Macrodiplax cora & 17 & 20 & - \\
\hline 6 & Neurothemis fluctuans & 23 & 20 & 7 \\
\hline 7 & Neurothemis ramburii & 13 & 15 & 3 \\
\hline 8 & Neurothemis terminata & 33 & 34 & 15 \\
\hline 9 & Orthetrum crysis & - & 14 & 2 \\
\hline 10 & Orthetrum sabina & 40 & 38 & 12 \\
\hline 11 & Orthetrum testaceum & 46 & 37 & 9 \\
\hline 12 & Pantala flavescens & 26 & 37 & - \\
\hline 13 & Tholymis tillarga & 24 & 35 & 15 \\
\hline \multirow[t]{3}{*}{14} & Urothemis signata & 8 & 27 & - \\
\hline & \multirow{2}{*}{\multicolumn{4}{|c|}{$\begin{array}{l}\text { Subordo Zygoptera } \\
\text { C. Famili Chlorocyphidae }\end{array}$}} \\
\hline & & & & \\
\hline \multirow[t]{2}{*}{15} & Libellago lineata & - & - & 17 \\
\hline & \multicolumn{4}{|c|}{ D. Famili Coenagrionidae } \\
\hline 16 & Agriocnemis femina & 27 & 25 & 19 \\
\hline 17 & Agriocnemis pygmaea & 15 & 10 & 14 \\
\hline 18 & Ceriagrion cerinorubellum & 66 & 40 & 16 \\
\hline 19 & Ischnura senegalensis & 20 & 12 & 17 \\
\hline 20 & Paracercion malayanum & - & 33 & - \\
\hline 21 & Pseudagrion microcephalum & - & 12 & - \\
\hline \multirow[t]{2}{*}{22} & Pseudagrion rubriceps & - & 15 & - \\
\hline & Jumlah Individu & 372 & 482 & 171 \\
\hline
\end{tabular}

Keterangan: SKM = Sungai Karang Mumus; BL = Bendungan Lempake; SB = Sungai Berambai

\section{Indeks Keanekaragaman, Indeks Kemerataan dan Dominansi}

Berdasarkan hasil data yang dikumpulkan dari ketiga lokasi penelitian didapatkan nilai Indeks Keanekaragaman $\left(\mathrm{H}^{\prime}\right)$, Indeks Kemerataan (E') dan Indeks Dominansi (D) dapat dilihat pada Tabel 2 sebagai berikut.

Tabel 2. Nilai Indeks Keanekaragaman (H'), Indeks Kemerataan (E') dan Dominansi (D) dari Odonata (capung) di Bendungan Lempake, Sungai Karang Mumus dan Sungai Berambai

\begin{tabular}{ccccc}
\hline No & Parameter & SKM & Lokasi Penelitian & SB \\
\hline 1 & Jumlah Spesies & 15 & 19 & 14 \\
2 & Jumlah Individu & 372 & 482 & 171 \\
3 & Indeks Keanekaragaman (H') & 2,516 & 2,853 & 2,533 \\
4 & Indeks Kemerataan (E') & 0,929 & 0,969 & 0,960 \\
5 & Indeks Dominansi (D) & 0,094 & 0,062 & 0,084 \\
\hline
\end{tabular}




\section{Indeks Kesamaan Jaccard (SJ)}

Berdasarkan hasil data yang dikumpulkan dari ketiga lokasi penelitian diperoleh nilai Indeks Jaccard (SJ) seperti tersaji pada Tabel 3 sebagai berikut.

Tabel 3. Nilai Kesamaan Jaccard (SJ)

\begin{tabular}{cccc}
\hline Lokasi & \multicolumn{3}{c}{ Nilai Kesamaan Jaccard } \\
SKM & BL & SB \\
\hline SKM & - & 0,789 & 0,526 \\
BL & & - & 0,500 \\
SB & & & - \\
\hline
\end{tabular}

Keterangan: SKM = Sungai Karang Mumus; BL = Bendungan Lempake; SB = Sungai Berambai

\section{Faktor Abiotik Kawasan Perairan Bendungan Lempake, Sungai Karang Mumus dan Sungai Berambai}

Pengukuran terhadap faktor-faktor abiotik di setiap lokasi pengambilan data dilakukan secara kuantitatif dan didapatkan nilai suhu, kelembaban dan $\mathrm{pH}$ air untuk kawasan perairan bendungan Lempake, sungai Karang Mumus dan sungai Berambai dapat dilihat pada Tabel 4.

Tabel 4. Nilai Faktor Abiotik dari Bendungan Lempake, Sungai Karang Mumus dan Sungai Berambai.

\begin{tabular}{|c|c|c|c|c|}
\hline \multirow[b]{2}{*}{ No } & \multirow[b]{2}{*}{ Keterangan } & \multicolumn{3}{|c|}{ Nilai Rata-rata pH air dan Suhu } \\
\hline & & $\begin{array}{l}\text { Sungai Karang } \\
\text { Mumus }\end{array}$ & $\begin{array}{l}\text { Bendungan } \\
\text { Lempake }\end{array}$ & $\begin{array}{c}\text { Sungai } \\
\text { Berambai }\end{array}$ \\
\hline 1 & pH Air & 7,1 & 7,0 & 7,1 \\
\hline $\begin{array}{l}2 \\
3\end{array}$ & $\begin{array}{c}\text { Suhu } \\
\text { Kelembaban Relatif (RH\%) }\end{array}$ & $\begin{array}{l}29,9^{\circ} \\
87 \%\end{array}$ & $\begin{array}{r}31^{\circ} \\
86 \%\end{array}$ & $\begin{array}{l}28,2^{\circ} \\
90 \%\end{array}$ \\
\hline
\end{tabular}

\section{Famili Chlorocyphidae}

Famili Chlorocyphidae berkembang biak di air mengalir, seperti aliran sungai di dalam hutan dan cenderung berada di tempat yang teduh (Hamalainen, 2001). Chlorocyphidae sering didapati bertengger di ujung ranting. Pada umumnya Chlorocyphidae tidak bepergian jauh dari aliran air tempat mereka berkembang biak (Silsby, 2001). Chlorocyphidae merupakan famili dari subordo Zygoptera yang paling sedikit ditemukan jenisnya, dari ketiga lokasi kawasan perairan hanya di dapatkan satu spesies yaitu Libellago lineata, spesies ini di dapatkan di kawasan sungai Berambai (Gambar 1), berikut deskripsinya.

\section{Libellago lineata}

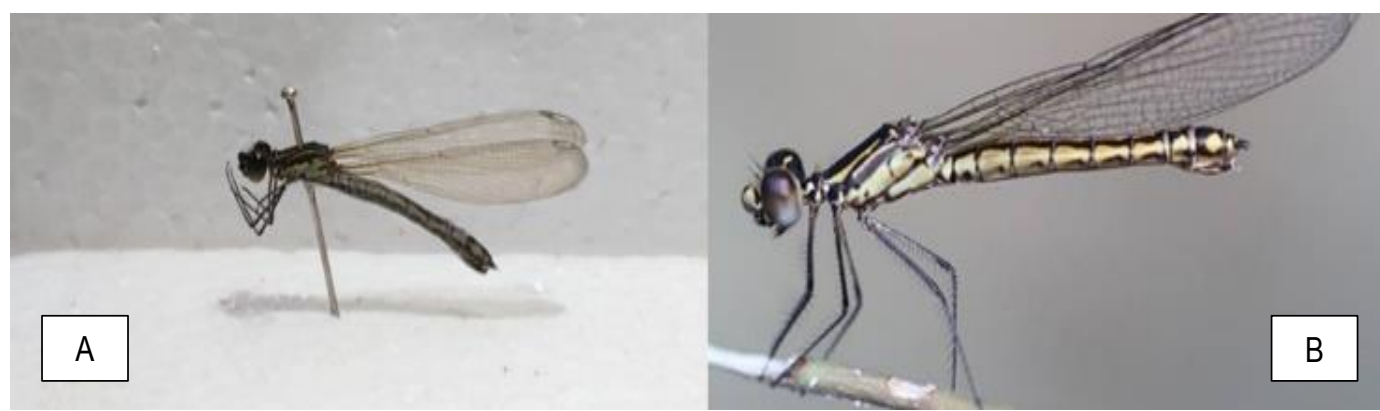

Gambar 1. (A) L. lineata (Sumber: Koleksi Pribadi, 2018); (B) L. lineata (Sumber: Suharni, 1991)

Odonata (capung) bertubuh pendek, pada spesies jantan memiliki warna dominan kuning dan hitam. Mata majemuk hitam kecoklatan. Toraks kuning cerah dengan strip-strip vertical hitam tebal. Abdomen berwarna kuning-hitam (Gambar 1). Warna kuning dari pangkal abdomen berangsur menghilang dan digantikan dengan warna hitam. Umbai berwarna hitam. Sayap transparan dan lebih 
panjang daripada abdomen. Di bagian pangkal sayap terdapat bercak kuning dengan pterostigma hitam. Capung Betina berwarna coklat (Setiyono et al., 2017). Jenis ini hanya dapat ditemukan di perairan yang masih bersih (Dwari et al., 2018).

\section{Famili Coenagrionidae}

Famili Coenagrionidae dari subordo Zygoptera ditemukan sebanyak 7 spesies yaitu Agriocnemis femina, Agriocnemis pygmaea, Ceriagrion cerinorubellum dan Ischnura senegalensis yang ditemukan diseluruh lokasi pengamatan, sedangkan untuk spesies Paracercion malayanum, Pseudagrion microcephalum dan Pseudagrion rubriceps ditemukan hanya di kawasan bendungan Lempake. Hampir semua spesies Odonata (capung) jarum akan sering di temui di berbagai jenis habitat air, dari saluran air sampai rawa-rawa dan hutan rawa (Gullan \& Craston, 2010), berikut deskripsinya.

\section{Agriocnemis femina}

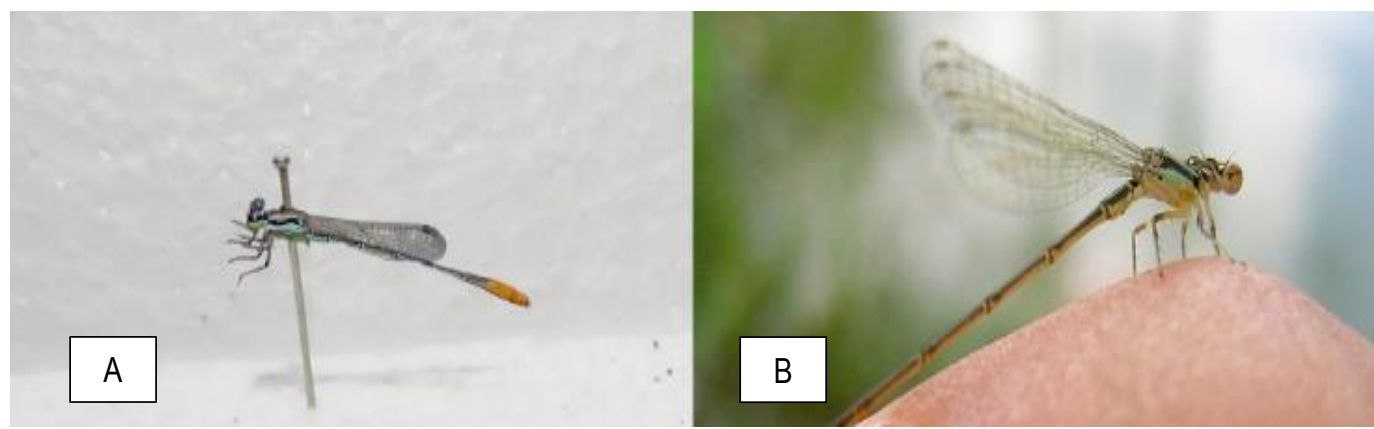

Gambar 2. (A) A. femina (Sumber: Koleksi Pribadi, 2018); (B) A. femina (Sumber: Subagyo, 2016)

Odonata (capung) bertubuh pendek. Jantan memiliki warna dominan kuning dan hitam. Mata majemuk hitam kecoklatan. Toraks kuning cerah dengan strip-strip vertical hitam tebal.Abdomen berwarna kuning-hitam (Gambar 2). Setiyono et al. (2017) menyatakan bahwa warna kuning dari pangkal abdomen berangsur menghilang dan digantikan dengan warna hitam. Umbai berwarna hitam.Sayap transparan dan lebih panjang daripada abdomen. Di bagian pangkal sayap terdapat bercak kuning dengan pterostigma hitam. Betina warna coklat.

\section{Agriocnemis pygmaea}

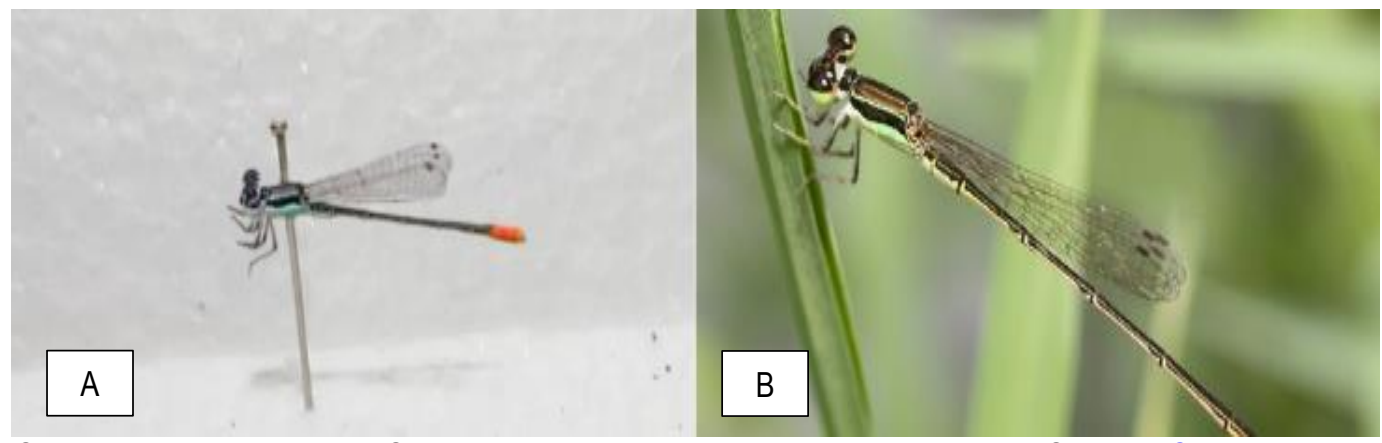

Gambar 3. (A) A. pygmaea (Sumber: Koleksi Pribadi, 2018); (B) A. pygmaea (Sumber: Subagyo, 2016)

Odonata (capung) jarum berukuran kecil. Mata majemuk hitam pada bagian atas dan hijau pada bagian bawah. Toraks bagian atas bergaris hitam tebal dengan garis hijau sempit. Abdomen hitam pada bagian dorsal dan hijau pada bagian ventral, serta warna jingga mencolok pada R8-R10 dan umbai (Gambar 3). Setiyono et al. (2017) menambahkan cerci lebih panjang daripada paraproct. Tungkai berwarna hitam. 


\section{Ceriagrion cerinorubellum}

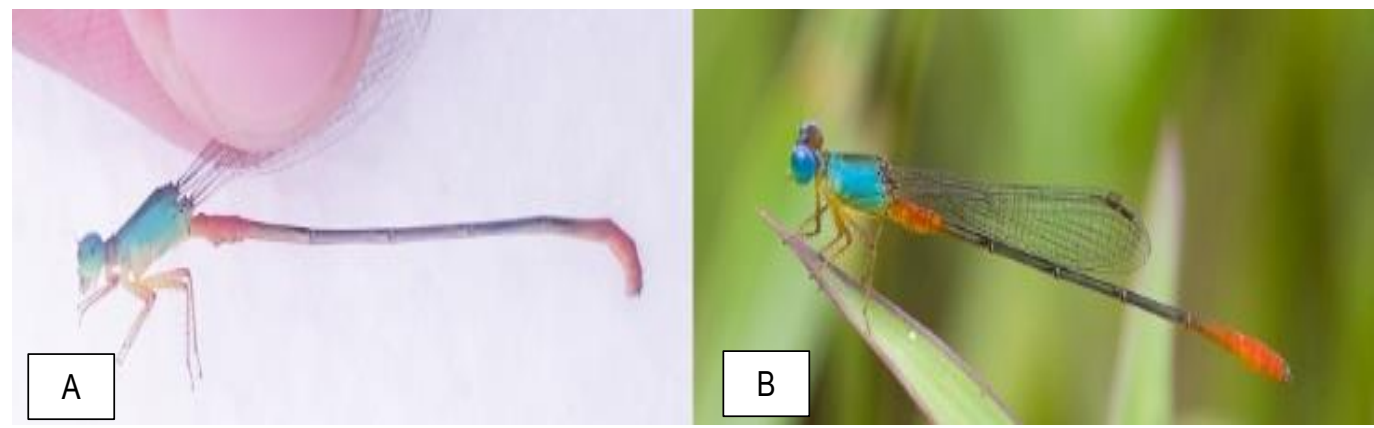

Gambar 4. (A) C. cerinorubellum (Sumber: Koleksi Pribadi, 2018); (B) C. cerinorubellum (Sumber: Suharni, 1991)

Odonata (capung) jarum berukuran sedang. Jantan memiliki mata berwarna hijau. Toraks berwarna hijau kekuningan. Abdomen berwarna jingga-hitam. R8-R10 berwarna jingga. Umbai berwarna hitam. Sayap transparan dengan pterostigma berwarna coklat. Betina mirip jantan tetapi dengan warna yang lebih kusam (Gambar 4). Gullan and Cranston (2010) menyatakan bahwa Ceriagrion cerinorubellum merupakan spesies Odonata (capung) jarum yang sering di temui di berbagai jenis habitat air, dari saluran air sampai rawa-rawa dan hutan rawa.

\section{Ischnura senegalensis}

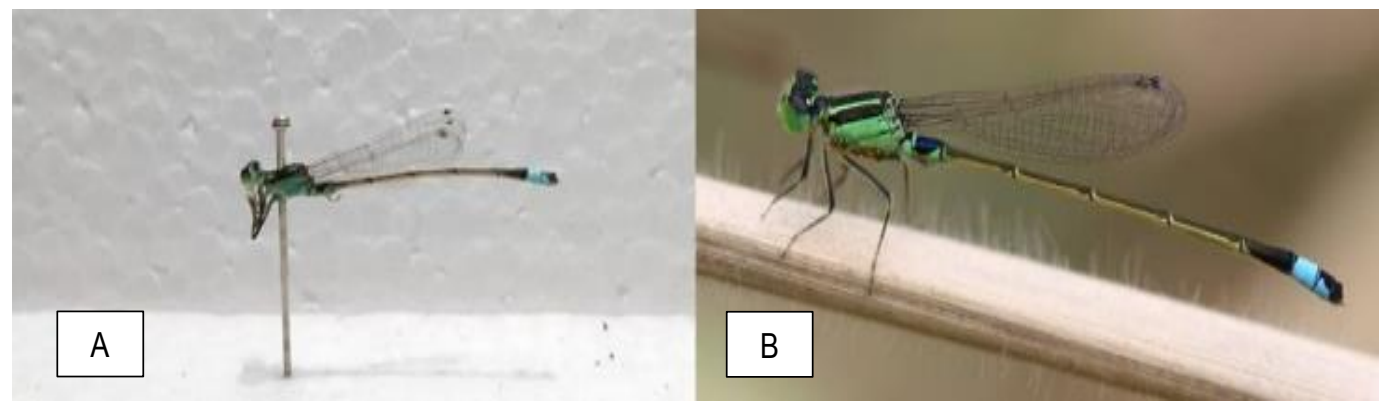

Gambar 5. (A) I. senegalensis (koleksi Pribadi); (B) I. senegalensis (Sumber: Suharni, 1991)

Odonata (capung) jarum berukuran sedang. Tubuh didominasi warna hijau dan hitam. Mata majemuk atas hitam dan hijau kebiruab di bagian bawah (Gambar 5). Jantan memiliki strip hitam tebal pada toraks bagian atas. Bagian dorsal abdomen berwarna hitam dengan bercak biru lebar pada R2 dan R8. R9 berwarna biru muda membatasi warna hitam pada R8 dan R10. Tungkai hitam di bagian atas dan biru di bagian bawah. Gullan and Craston (2010) menambahkan bahwa betina memiliki banyak variasi warna, bagian dorsal abdomen berwarna hitam dan berukuran lebih besar namun ada juga individu betina yang mirip dengan individu jantan, dengan tubuh lebih hijau kekuningan. Individu lain berwarna jingga pada toraks. Tungkai atas hitam dan bagian bawah kuning kecoklatan.

\section{Paracercion malayanum}

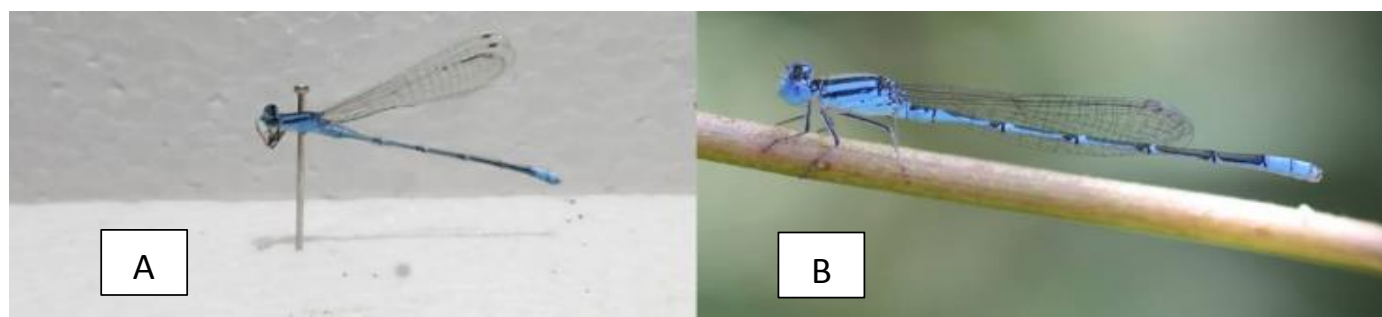

Gambar 6. (A) P. malayanum (Sumber: Koleksi Pribadi, 2018); (B) P. malayanum (Sumber: Suharni, 1991) 
Odonata (capung) jarum berukuran kecil. Kepala biru, toraks biru dengan 1 garis hitam di bagian dorsal tengah, 2 pita antehumeral berwarna hitam, abdomen biru dengan garis hitam memanjang. Sayap transparan (Gambar 6). Umbai terlihat tumpul. Paracercion malayanum sering hinggap sejajar di atas tanaman air yang mengapung di permukaan.

\section{Pseudagrion microcephalum}

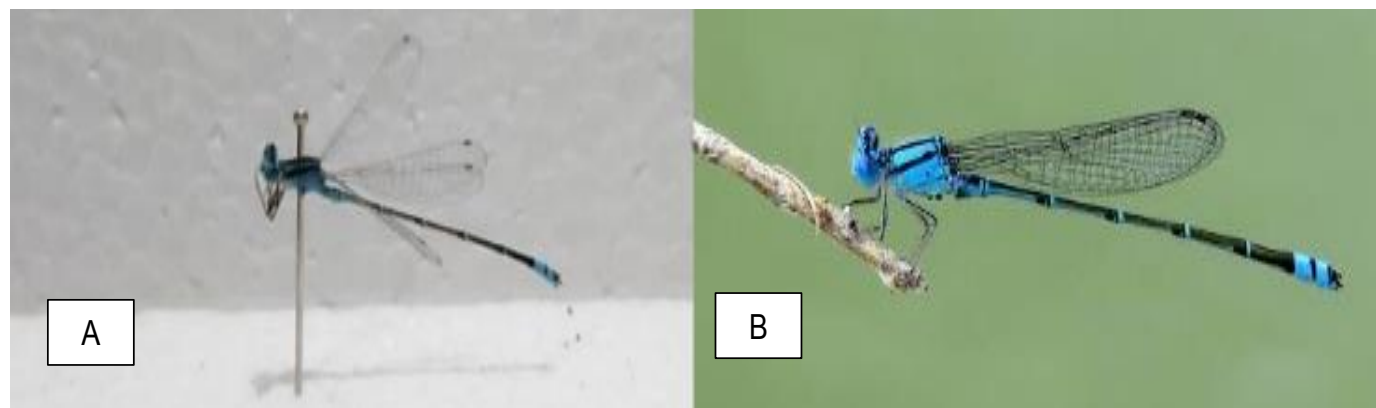

Gambar 7. (A) P. microchepalum (Sumber: Koleksi Pribadi, 2018); (B) P. microchepalum (Sumber: Suharni, 1991)

Odonata (capung) jarum berukuran sedang. Kepala biru, toraks biru langit terang. Mata majemuk dan kepala bagian atas bergaris hitam melintang. Pada bagian dorsal sintoraks terdapat 3 garis hitam (Gambar 7). Abdomen hitam kebiruan. R8-R9 berwarna biru muda dan terdapat pita hitam diantara kedua ruas tersebut. Betina berwarna biru abu-abu atau hijau kebiruan.

\section{Pseudagrion rubriceps}

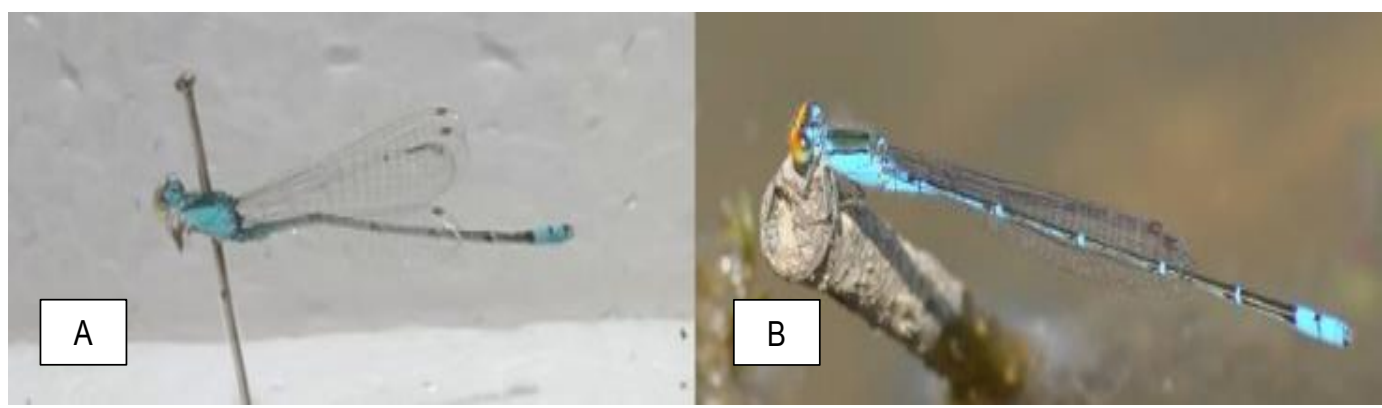

Gambar 8. (A) P. rubriceps (Sumber: Koleksi Pribadi, 2018); (B) P. rubriceps (Sumber: Suharni, 1991)

Odonata (capung) jarum berukuran sedang. Memiliki warna yang mirip dengan $P$. microcephalum. Perbedaannya terdapat pada frons dan sebagian mata majemuknya yang berwarna jingga (Gambar 8). Sintoraks berwarna biru kehijauan pada bagian dorsal dan biru di bagian ventral R8R10 sama dengan toraks. Betina memiliki warna lebih pucat dengan warna jingga kehijauan.

\section{Famili Gomphidae}

Famili Gomphidae merupakan famili dari subordo Anisoptera yang paling sedikit ditemukan jenisnya dalam penelitian ini, dari ketiga lokasi kawasan perairan hanya ditemukan satu spesies yaitu Ictinogomphus decoratus, spesies ini ditemukan di kawasan sungai Berambai. Spesies ini umumnya ditemukan pada perairan yang bersih (Gullan \& Craston, 2010). 
1. Ictinogomphus decorates

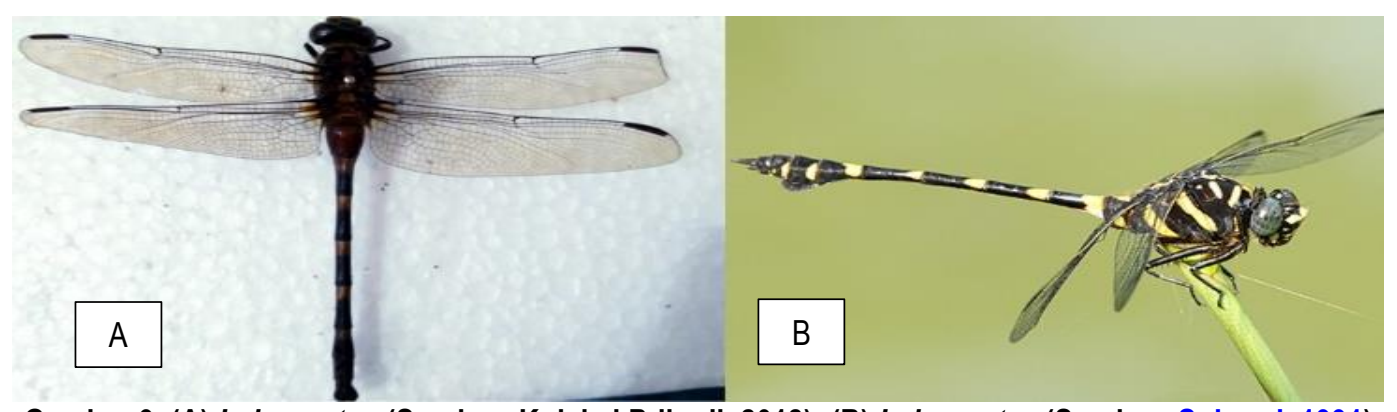

Gambar 9. (A) I. decoratus (Sumber: Koleksi Pribadi, 2018); (B) I. decorates (Sumber: Suharni, 1991)

Odonata (capung) berukuran besar, memiliki corak warna loreng kuning dan hitam dari thoraks hingga abdomen (Gambar 9). Mata majemuk terpisah berwarna abu-abu kebiruan. Jantan memiliki perbesaran pada abdomen R8-R10 (R: segmen dari abdomen) menyerupai gada dan ujung dengan sepasang umbai meruncing sehingga terlihat seperti tombak (Setiyono et al., 2017). Betina memiliki R8R10 lebih ramping

\section{Famili Libellulidae}

Famili Libellulidae dari subordo Anisoptera ditemukan sebanyak 13 spesies dan merupakan famili dengan jenis paling banyak yang ditemukan selama penelitian, masing-masing spesiesnya adalah Neurothemis fluctuans, Neurothemis ramburii, Neurothemis terminate, Orthetrum sabina, Orthetrum testaceum dan Tholymis tillarga yang ditemukan di seluruh lokasi pengamatan, kemudian Acisoma panorpoides, Brachydiplax chalybea, Macrodiplax cora, Pantala flavescens dan Urothemis signata yang ditemukan di dua lokasi pengamatan yaitu kawasan sungai Karang Mumus dan Bendungan Lempake. Orthetrum crysis ditemukan di dua lokasi pengamatan yaitu Bendungan Lempake dan sungai Berambai, lalu yang terakhir adalah Cratilla lineata yang hanya ditemukan di kawasan pinggir sungai Berambai, berikut deskripsinya:

\section{Acisoma panorpoides}
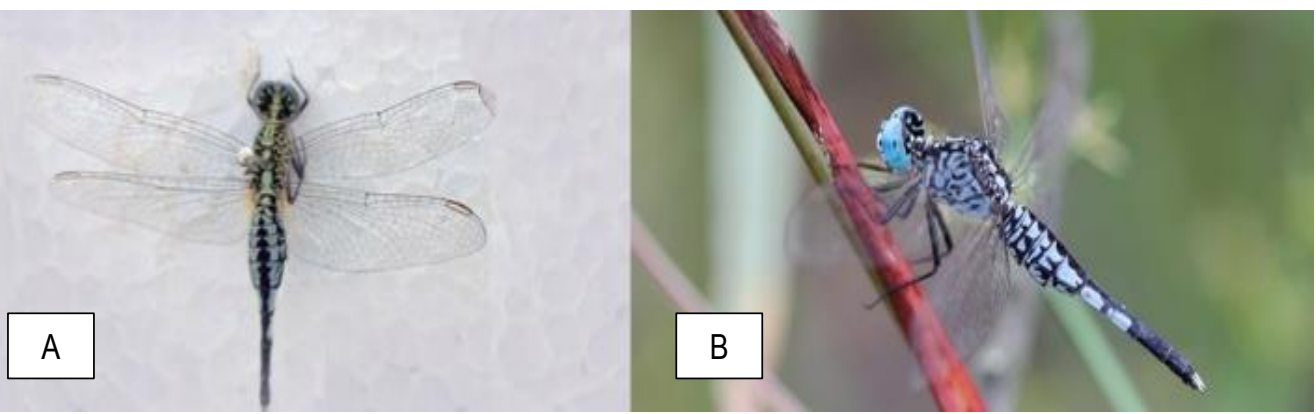

Gambar 10. (A) A. panorpoides (Sumber: Koleksi Pribadi, 2018); (B) A. panorpoides (Sumber: Suharni, 1991)

Odonata (capung) berukuran kecil, bagian toraks dan sebagian besar abdomen berwarna biru, memiliki pola khas berwarna hitam pada sisi lateral abdomen, serta terdapat garis hitam di sepanjang bagian dorsal abdomen (Gambar 10). Bagian pangkal abdomen menggembung menyerupai terompet oleh karena itu biasa disebut sebagai trumpet tail. R8-R10 (R= R= Segmen Abdomen) seluruhnya hitam dan terdapat umbai berwarna biru muda. Sayap transparan dengan noktah kuning. Jantan berwarna biru sedangkan betinanya berwarna hijau. 
2. Brachydiplax chalybea

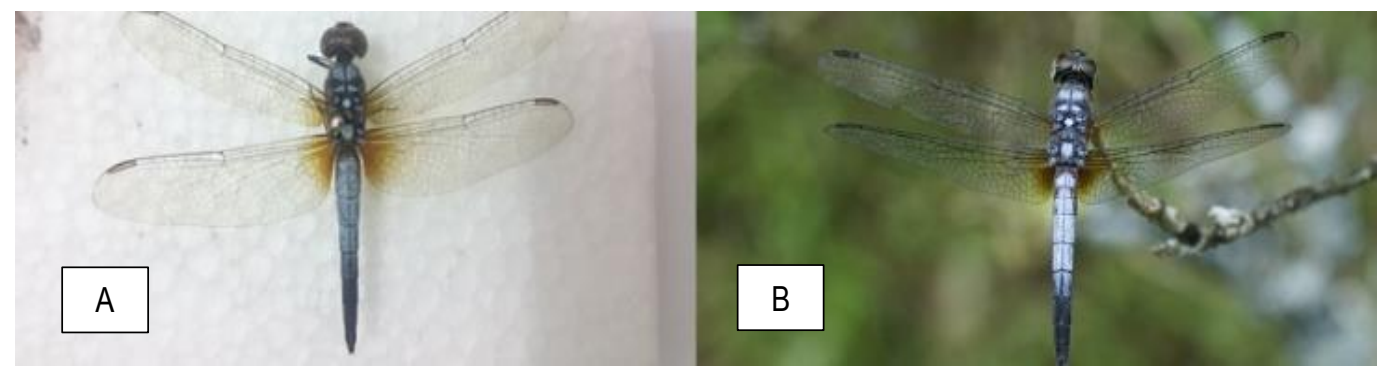

Gambar 11. (A) B. chalybea (Sumber: Koleksi Pribadi, 2018); (B) B. chalybea (Sumber: Suharni, 1991)

Jantan dengan panjang tubuh $31,5-38 \mathrm{~mm}$, sayap depan $25-30,5 \mathrm{~mm}$, sayap belakang $24,5-29$ $\mathrm{mm}$, toraks sisi lateral dan abdomen sisi ventral berwarna cokelat, sisi dorsal toraks dan dorsal abdomen diselimuti serbuk pruinescent berwarna biru keputih-putihan, abdomen segmen 7-10 hitam (Gambar 11). Betina dengan toraks dan abdomen berwarna cokelat dengan corak hitam (Subagyo, 2016).

\section{Cratilla lineata}

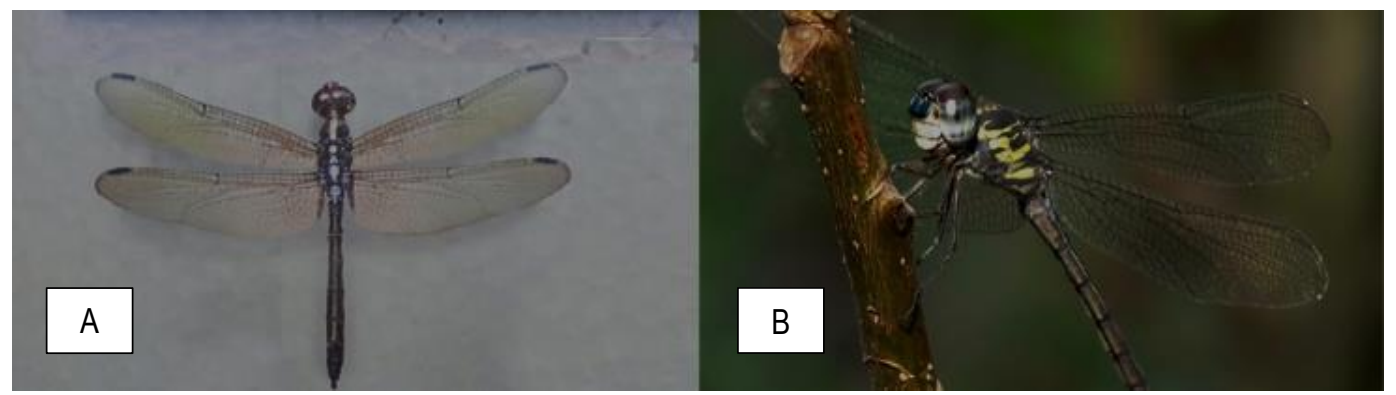

Gambar 12. (A) C. lineata (Sumber: Koleksi Pribadi, 2018); (B) C. lineata (Sumber: Suharni, 1991)

Odonata (capung) ini biasa disebut capung-sambar hutan, berukuran sedang, mata berwarna coklat pada bagian atas dan hijau pada bagian bawah. Toraks hitam metalik dengan garis berwarna kuning. Abdomen berwarna hitam dengan garis kuning pada bagian dorsal. Individu muda memiliki garis kuning pada abdomen bagian lateral (Gambar 12). Garis kuning dari toraks hingga $\mathrm{R} 8$ ( $\mathrm{R}=$ Segmen Abdomen) menjadi ciri khas spesies ini. Sayap transparan dengan pterostigma hitam. Betina miliki cuping pada R9. Cratilla lineata bersifat soliter, sering dijumpai hinggap pada ranting di hutan dengan intensitas cahaya yang rendah (Setiyono et al., 2017).

\section{Macrodiplax cora}

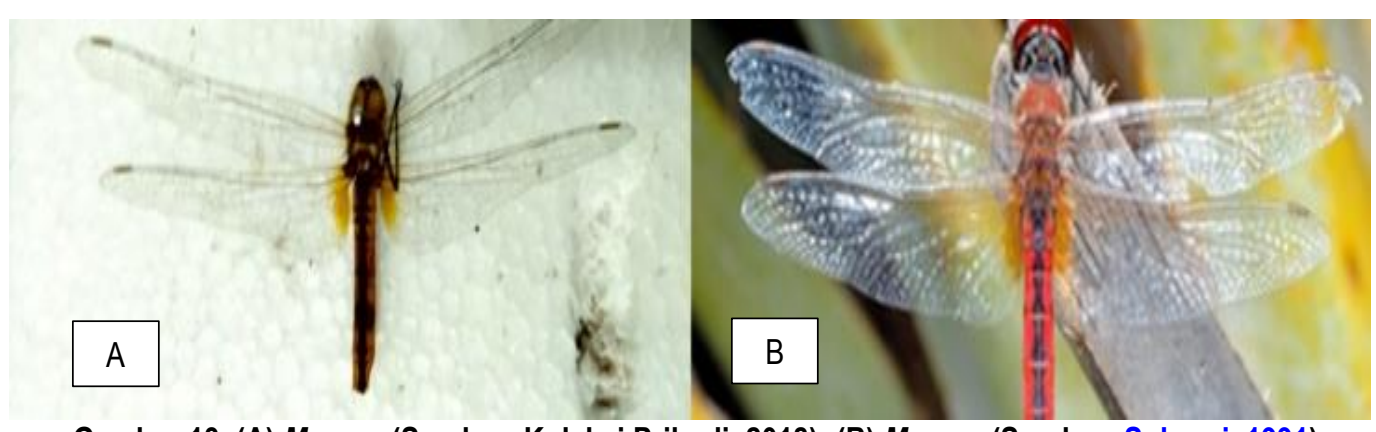

Gambar 13. (A) M. cora (Sumber: Koleksi Pribadi, 2018); (B) M. cora (Sumber: Suharni, 1991) 
Odonata (capung) ini biasa disebut capung-jemur pesisir, berukuran sedang. Jantan memiliki mata majemuk dan frons merah gelap. Toraks merah kecoklatan dengan beberapa garis hitam. Abdomen berwarna merah dengan garis hitam tebal pada bagian dorsal setiap ruas. Sayap transparan dengan sedikit warna jingga kecoklatan pada bagian pangkal, pterostigma jingga kecoklatan (Gambar 13). Betina memiliki mata majemuk merah kecoklatan pada bagian atas dan pucat pada bagian bawah. Frons kuning. Toraks kuning-jingga dengan garis hitam beralur pada bagian lateral. Abdomen kuningjingga dengan garis hitam yang nampak jelas pada bagian dorsal. Pterostigma jingga kecoklatan. Pada individu muda, garis hitam pada bagian atas abdomen masih samar. Macrodiplax cora sering ditemui hinggap pada tonggak/ranting dekat dengan perairan dengan intensitas cahaya yang tinggi. Biasanya memilih bertengger pada tonggakan yang tinggi (Setiyono et al., 2017).

\section{Neurothemis fluctuans}

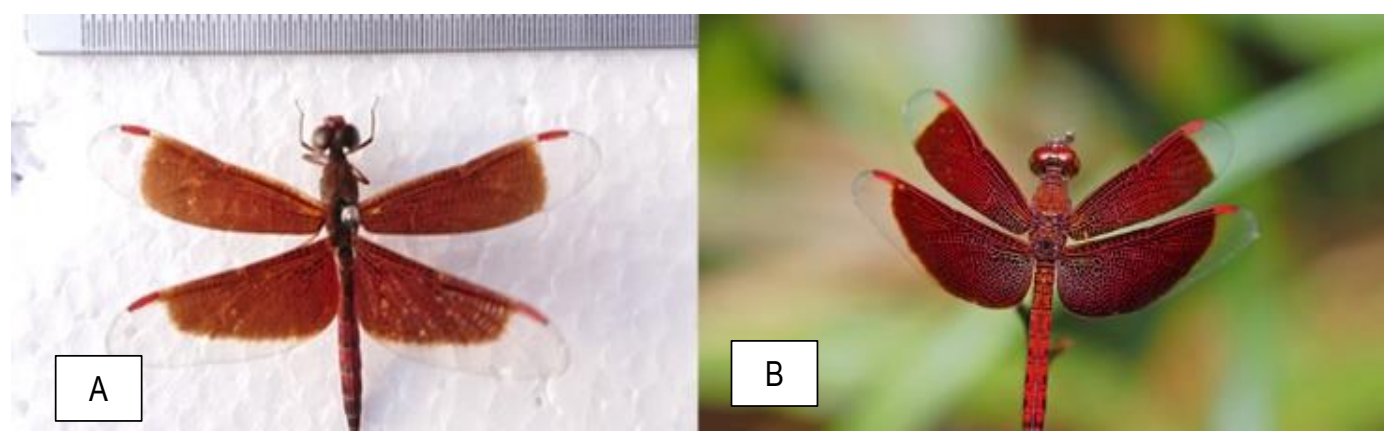

Gambar 14. (A) N. fluctuans (Sumber: Koleksi Pribadi, 2018); (B) N. fluctuans (Sumber: Suharni, 1991)

Odonata (capung) berukuran kecil. Jantan memiliki kepala, toraks, abdomen dan sayap yang berwarna merah, warna merah pada sayap belakang melengkung dari sisi kanan pterostigma menuju pangkal sayap (Gambar 14). Betina berwarna kuning dengan bercak hitam pada dorsal abdomen. Sayap transparan dengan sedikit bercak kuning pada bagian ujung sayap, pangkal sayap dan tepi anterior sayap (Setiyono et al., 2017).

\section{Neurothemis ramburii}

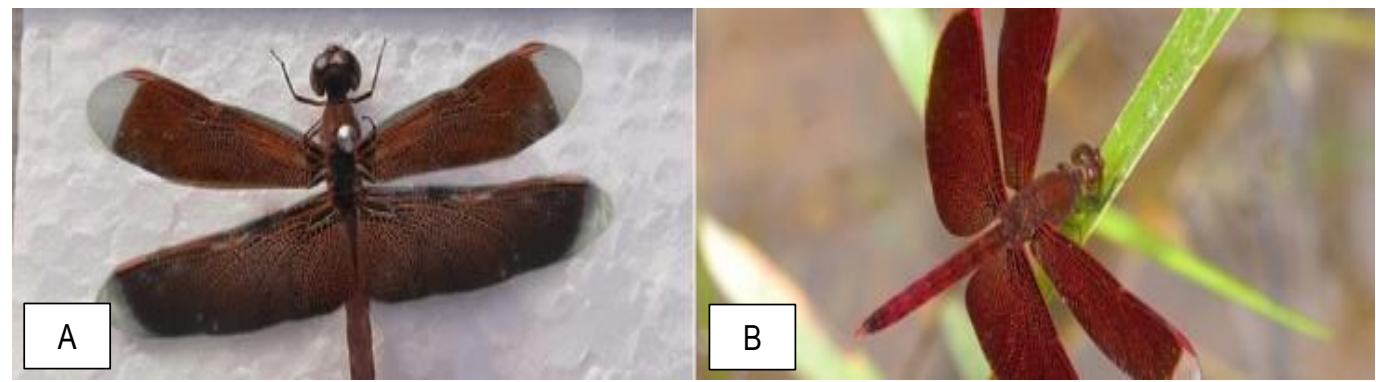

Gambar 15. (A) N. ramburii (Sumber: Koleksi Pribadi, 2018); (B) N. ramburii (Sumber: Suharni, 1991)

Odonata (capung) berukuran sedang. Jantan memiliki kepala, toraks, abdomen dan sayap yang berwarna merah, warna merah pada sayap belakang melengkung dari sisi kanan pterostigma menuju pangkal sayap. Bagian mata menyatu seperti garis tengah di atas kepala. Abdomen merah tua dengan garis hitam di bagian dorsal dan lateral (Gambar 15). Warna hitam berangsur menebal menuju ujung abdomen. R10 ( $R=$ segmen abdomen) hitam dengan umbai merah. Betina memiliki warna kuning kecoklatan. Sayap berwarna lebih tua daripada tubuhnya. Ujung sayap tansparan dan sayap belakang membulat di dasar. Ciri khusus yang dimiliki ialah pada ujung atas sayapnya memiliki titik merah. $N$. ramburii sering hinggap pada rerumputan, ranting kering, daun dan bebatuan (Setiyono et al., 2017). 
7. Neurothemis terminate
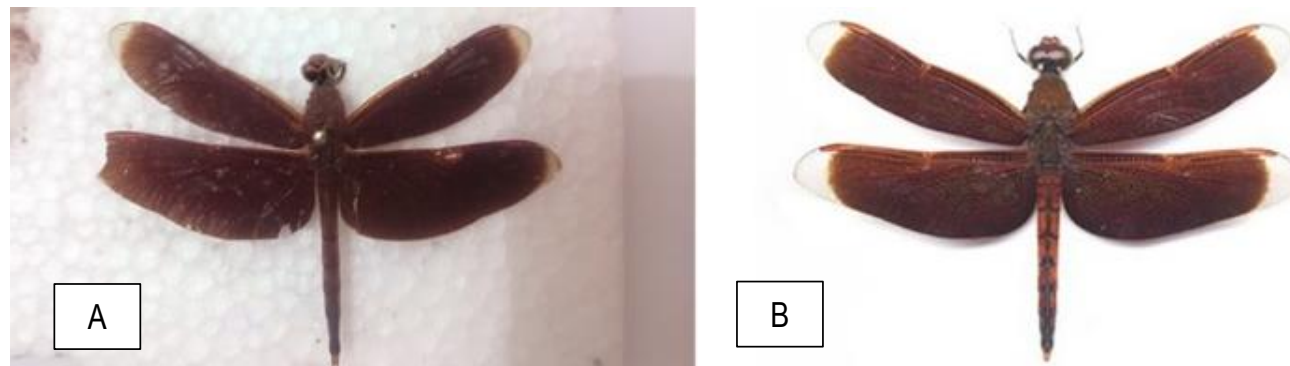

Gambar 16. (A) N. terminata (Sumber: Koleksi Pribadi, 2018); (B) N. terminata (Sumber: Suharni, 1991)

N. terminata sering hinggap pada rerumputan, ranting kering, daun dan bebatuan, tidak jarang berbaur dengan spesies $N$. fluctuans dan $N$. ramburii. Terbang dengan cepat dan jauh saat terganggu (Setiyono et al., 2017). Jantan memiliki panjang tubuh 39-42 mm, sayap depan 29-30,8 mm, sayap belakang $29-30 \mathrm{~mm}$, tubuh dan $3 / 4$ dari kedua pasang sayapnya didominasi warna merah hati. Mata majemuk sisi atas berwarna cokelat dan sisi bawah berwarna hijau, frons merah, toraks berwarna cokelat kemerahan, dan abdomen berwarna merah hati dengan pola hitam pada sisi dorsal dan lateral yang semakin menebal ke arah posterior (Gambar 16). Segmen 10 hitam dengan embelan putih gading, sayap berwarna merah hati dari pangkal sampai $3 / 4$ sayap atau mencapai pertengahan stigma dan selebihnya transparan, stigma berwarna merah (Subagyo, 2016).

\section{Orthetrum crisis}

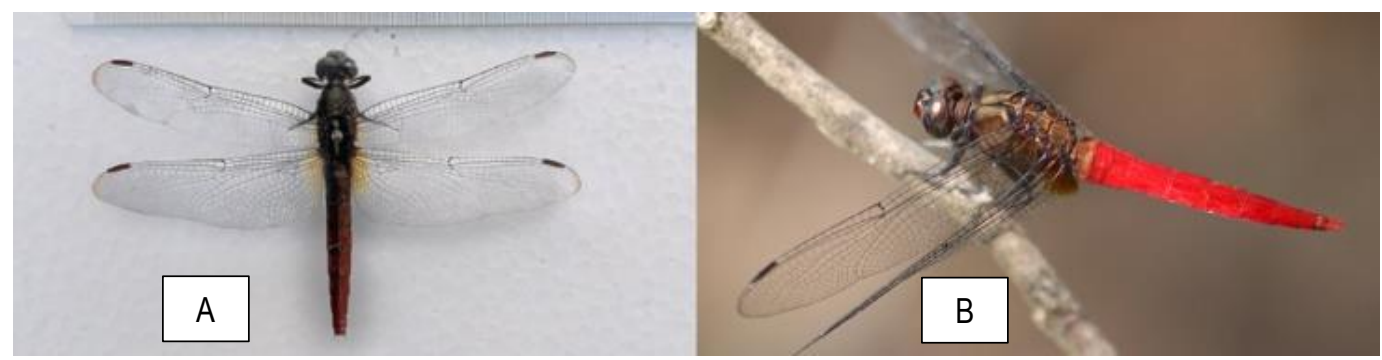

Gambar 17. (A) O. crysis (Sumber: Koleksi Pribadi, 2018); (B) O. crisis (Sumber: Suharni, 1991)

Odonata (capung) berukuran sedang. Jantan berwarna coklat dan merah. Mata biru abu-abu, frons merah, toraks coklat kemerahan. Abdomen merah cerah, terdapat rambut mirip kait kecil pada sisi ventral R2 (pada organ genital jantan), sangat jelas terlihat dari samping, kait tersebut merupakan ciri khusus dari spesies ini. Sayap transparan dengan pangkal kuning (Gambar 17). Setiyono et al. (2017) menjelaskan bahwa betina berwarna lebih suram, kuning kecoklatan pada toraks. Abdomen merah gelap. Sayap transparan dengan pangkal kuning.

\section{Orthetrum Sabina}

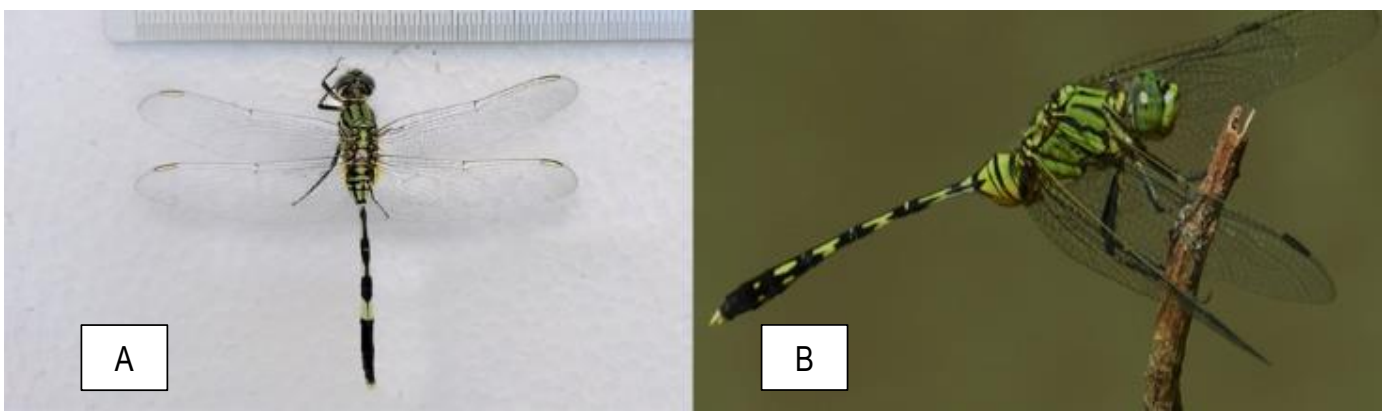

Gambar 18. (A) O. sabina (Sumber: Koleksi Pribadi, 2018); (B) O. sabina (Sumber: Suharni, 1991) 
O. sabina merupakan spesies kanibal, karena sering terlihat memakan spesies yang sama atau Odonata (capung) jenis lain yang lebih kecil. Sering hinggap pada rerumputan atau batang kayu saat kawin (Setiyono et al., 2017). Odonata (capung) berukuran sedang. Spesies ini sering disebut dengan nama capung tentara karena warna loreng hijau-hitam yang mirip dengan baju tentara. R1-R3 membesar dengan warna hijau kekuningan bergaris hitam (Gambar 18). R4-R6 ramping berwarna hitam-putih dan kembali membesar pada ujung R7-R10 (R= Segmen Abdomen).

\section{Orthetrum testaceum}

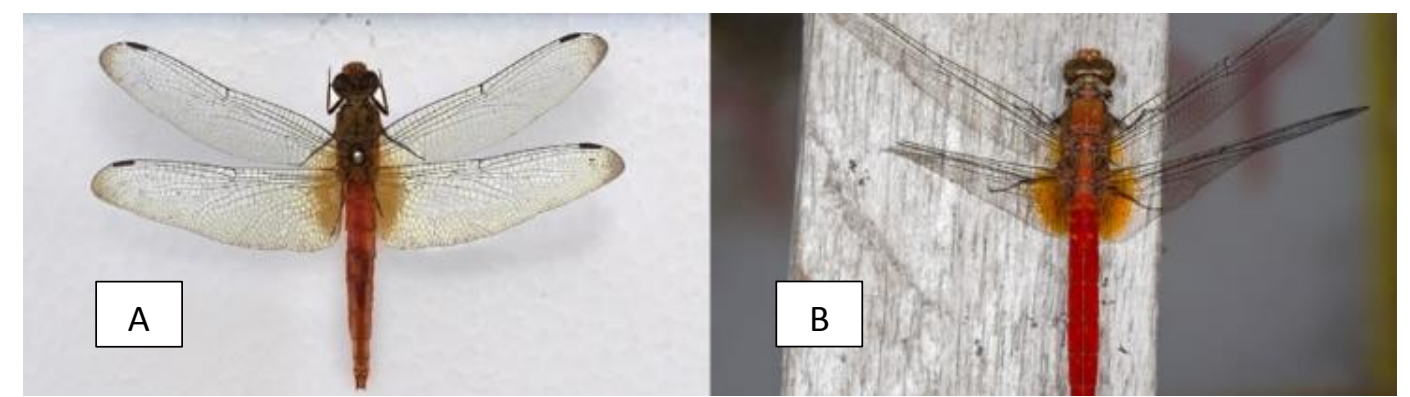

Gambar 19. (A) O. testaceum (Sumber: Koleksi Pribadi, 2018); (B) O. testaceum (Sumber: Suharni, 1991)

Odonata (capung) berukuran sedang. Jantan berwarna jingga kecoklatan pada bagian toraks dan merah terang pada abdomen. Mata majemuk abu-abu kecoklatan dengan frons merah. Sayap belakang coklat gelap pada bagian pangkal (Gambar 19). Sangat mirip dengan O. crisys yang membedakan adalah 0 . testaceum tidak memiliki kait pada bagian ventral R2. Di samping itu warna toraks dan mata 0 . testaceum lebih terang. Betina coklat kekuningan, dengan sayap belakang transparan pada seluruh bagian (Setiyono et al., 2017).

\section{Pantala flavescens}

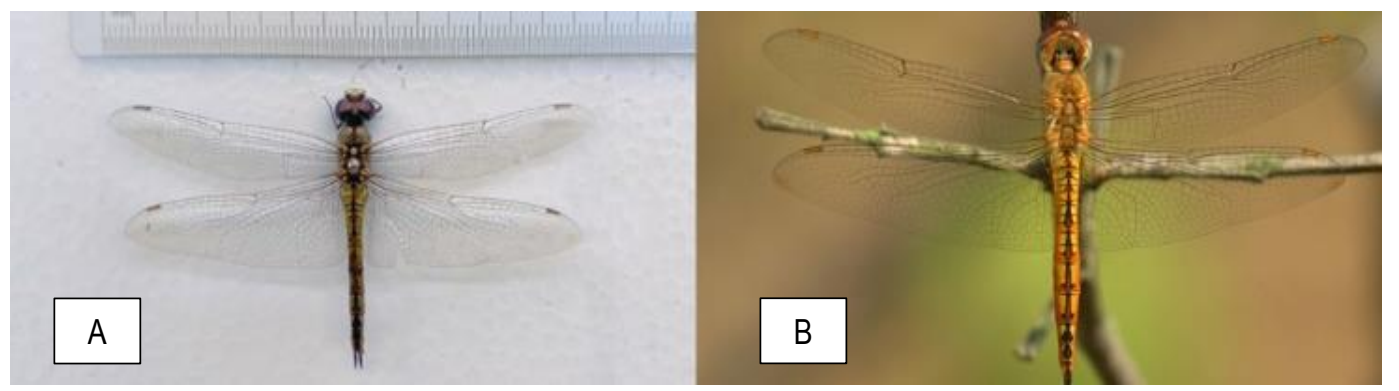

Gambar 20. (A) P. flavescens (Sumber: Koleksi Pribadi, 2018); (B) P. flavescens (Sumber: Suharni, 1991)

Odonata (capung) berukuran besar, berwarna dominan kuning kemerahan. Jantan dengan mata merah di bagian atas dan berangsur hijau kekuningan di sisi bawah. Toraks dan abdomen kuning kemerahan. Bagian dorsal dari abdomennya bergaris hitam dan semakin menebal menuju ujung. Umbai berwarna hitam. Sayap trasnparan, kekuningan pada bagian pangkal sayap belakang. Pterostigma merah kecoklatan (Gambar 20). Tubuh akan berwarna lebih merah pada fase dewasa. Betina kuning pucat. Mata berwarna merah muda pucat disisi atas dan abu-abu disisi bawahnya. Pterostigma kuning (Setiyono et al., 2017). 
12. Tholymis tillarga

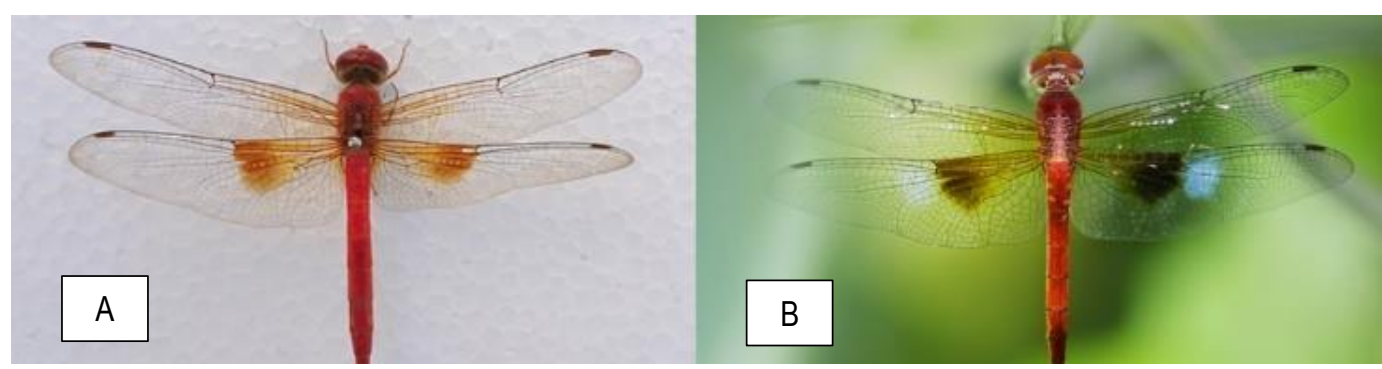

Gambar 21. (A) T. tillarga (Sumber: Koleksi Pribadi, 2018); (B) T. tillarga (Sumber: Suharni, 1991)

Odonata (capung) berukuran sedang. Jantan berwarna jingga kemerahan dengan mata majemuk berwarna merah kekuningan pada bagian atas dan kuning kehijauan pada bagian bawah. Jantan dapat dikenali dari sayap belakangnya yang memiliki corak coklat putih jelas pada bagian tengah sayap (Gambar 21). Betina memiliki warna yang lebih suram, yaitu coklat kekuningan tanpa warna putih pada sayap belakang. Individu muda mirip dengan betina. Tholymis tillarga aktif pada sore hari, pada siang hari hinggap secara vertical di batang rumput yang dekat dengan air (Setiyono et al., 2017).

\section{Urothemis signata}

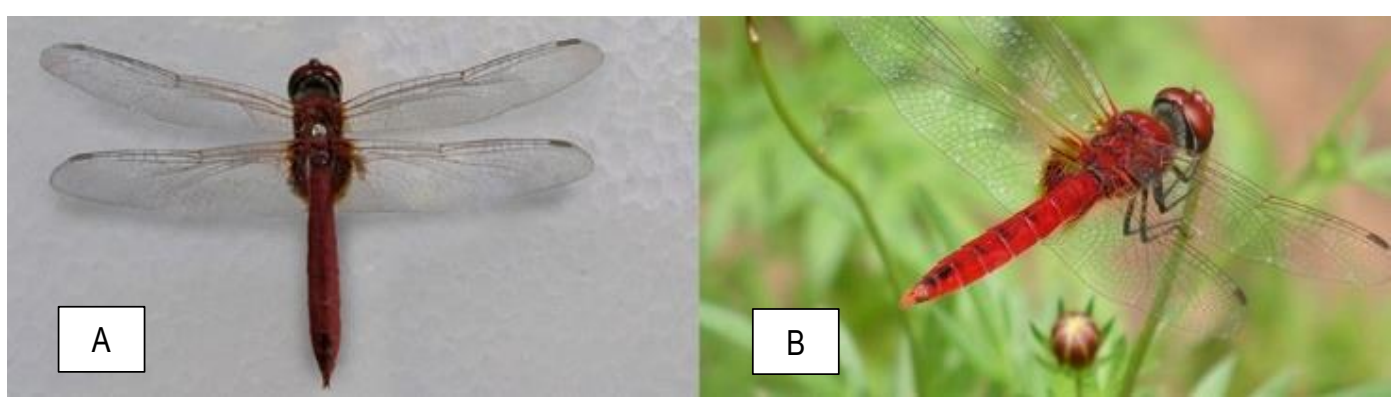

Gambar 22. (A) U. signata (Sumber: Koleksi Pribadi, 2018); (B) U. signata (Sumber: Suharni, 1991)

Odonata (capung) berukuran sedang. Jantan memiliki mata majemuk merah gelap di sisi atas dan cokelat gelap di sisi bawah. Toraks merah kecoklatan, abdomen merah cerah dengan 2 spot hitam tebal pada R8-R9 ( $R=$ segmen abdomen). Sayap transparan dengan cenasi merah dan hitam, pangkal cokelat gelap, pterostigma cokelat kehitaman (Gambar 22). Betina berwarna kekuningan. Mata majemuk merah kecokelatan di sisi atas dan abu-abu kehijauan di sisi bawah kekuningan (Setiyono et al., 2017).

Tabel 2 menyajikan data Nilai Indeks Keanekaragaman ( $\left.\mathrm{H}^{\prime}\right)$ tertinggi terdapat pada lokasi kawasan Bendungan Lempake dengan nilai 2,853, nilai ini didapatkan dari jumlah jenis Odonata (capung) yang lebih banyak ditemukan (19 spesies) di kawasan Bendungan Lempake. Indeks Keanekaragaman di Bendungan Lempake ini sedikit lebih tinggi jika dibandingkan dengan dua lokasi lain yaitu 2,516 untuk sungai Karang Mumus dan 2,533 untuk sungai Berambai. Faktor-faktor yang mempengaruhinya antara lain karena Bendungan Lempake memiliki kawasan perairan terbuka yang luas. Sementara, daerah sungai Karang Mumus berada di tengah pemukiman masyarakat, banyak aktivitas tranportasi perahu di kawasan tersebut dan kurangnya tumbuhan air yang terdapat di kawasan tersebut sehingga kurang mendukung Odonata (capung) dalam beraktivitas, misalnya untuk berlindung dan berkembang biak. Hal ini sejalan dengan pernyataan Setiyono et al. (2017) bahwa perairan terbuka 
lebih disukai kelompok Odonata, tidak terlalu banyak aktivitas manusia yang mengganggu, serta terdapat banyak tanaman air sehingga dapat mendukung proses perkembangan spesies Odonata (capung) tertentu yang tidak ditemukan di lokasi lainnya.

Faktor-faktor yang kemungkinan mempengaruhi lokasi kawasan perairan sungai Berambai yaitu lokasi sungai Berambai yang merupakan salah satu kawasan wisata masyarakat sekitar Desa Berambai dan Kota Samarinda, sehingga terdapat cukup banyak aktivitas manusia di kawasan tersebut,salah satunya terdapat lahan perkebunan sawit, yang memerlukan pupuk dan pestisida berbahan kimia yang mempengaruhi keadaan lingkungan di sekitarnya. Menurut Nugrahani (2014), aktivitas manusia di sekitar badan air dapat menyebabkan pencemaran badan air sehingga menyebabkan lebih rendahnya tingkat keanekaragaman jenis Odonata (capung). Dalzochio et al., (2011) melaporkan bahwa keanekaragaman Odonata yang cukup tinggi pada perairan tawar di Brazil sangat dipengaruhi oleh kondisi perairan sangat mendukung perkembangbiakan Odonata. Berdasarkan kriteria penilaian penggolongan kualitas lingkungan (Krebs, 1989) seluruh kawasan perairan ini memiliki tingkat keanekaragaman sedang, karena jumlah nilai $\mathrm{H}^{\prime}$ lebih dari 1,5 dan kurang dari 3,5. Hal ini menyatakan bahwa semua kawasan yang diteliti masih cukup layak untuk habitat capung (Odonata).

Berdasarkan Tabel 2, nilai E' di kawasan sungai Karang Mumus adalah 0,929; nilai E' Bendungan Lempake adalah 0,969 dan di kawasan sungai Berambai adalah 0,960. Indeks Kemerataan Jenis (E') dapat menggambarkan kestabilan suatu komunitas, berdasarkan kriteria penilaian pembobotan kualitas lingkungan (Odum, 2005) ketiga kawasan perairan ini termasuk dalam tingkat kemerataan yang cukup tinggi, karena nilai E' hampir mendekati 1 yang berarti tingkat kemerataan spesies di ketiga kawasan tersebut merata. Perbedaan nilai E' ini dipengaruhi oleh banyak faktor diantaranya adalah spesies Odonata (capung) yang ditemukan di setiap kawasan perairan, dimana hasil pengamatan pada setiap kawasan sungai Karang Mumus, di kawasan Bendungan Lempake, dan Kawasan sungai Berambai berbeda jumlah dan spesiesnya.

Pada Tabel 2, terlihat bahwa nilai dominansi di kawasan sungai Karang Mumus adalah 0,094, nilai dominansi di kawasan Bendungan Lempake adalah 0,062 dan nilai dominansi di kawasan sungai Berambai adalah 0,084 , menunjukkan bahwa tidak ada spesies yang dominan atau mendominasi di semua lokasi penelitian. Indeks Dominansi merupakan nilai yang dapat menggambarkan adanya dominansi (penguasaan) dari spesies tertentu dalam suatu komunitas. Menurut Odum (2005), jika nilai $\mathrm{D}$ mendekati 0 berarti hampir tidak terdapat dominansi pada suatu kawasan tersebut dan jika nilai $D$ mendekati 1 berarti terdapat spesies yang mendominansi di suatu kawasan tersebut. Perbandingan kesamaan jenis Odonata pada masing-masing lokasi dianalisis dengan menggunakan cluster analysis seperti yang terlihat pada Gambar 23.

Nilai Kesamaan Jaccard (SJ) yang disajikan pada Tabel 3, yaitu nilai tertinggi ditemukan antara sungai Karang Mumus dan Bendungan Lempake yaitu 0,789, lebih dari setengah jumlah spesies Odonata (capung) sama dari kedua kawasan perairan tersebut sama. Hal ini didukung karena di kedua kawasan perairan, sama-sama merupakan perairan yang terdapat banyak aktivitas manusia (permukiman dan wisata). Nilai Kesamaan Jaccard (SJ) antara sungai Karang Mumus dengan sungai Berambai adalah 0,526 serta antara Bendungan Lempake dan sungai Berambai adalah 0,500. Nilai tersebut menunjukan bahwa $50 \%$ jenis capung yang ditemukan di kedua kawasan ini lebih kurang sama. Walaupun mempunyai jumlah kesamaan spesies yang lebih banyak dibandingkan dengan kawasan sungai Karang Mumus dan sungai Berambai tetapi nilai SJ dari kedua kawasan ini lebih rendah karena ditemui 3 spesies yang hanya terdapat pada kawasan perairan Bendungan Lempake sehingga hal ini mempengaruhi nilai dari hasil perhitungan Indeks Kesamaan Jaccard (SJ). 


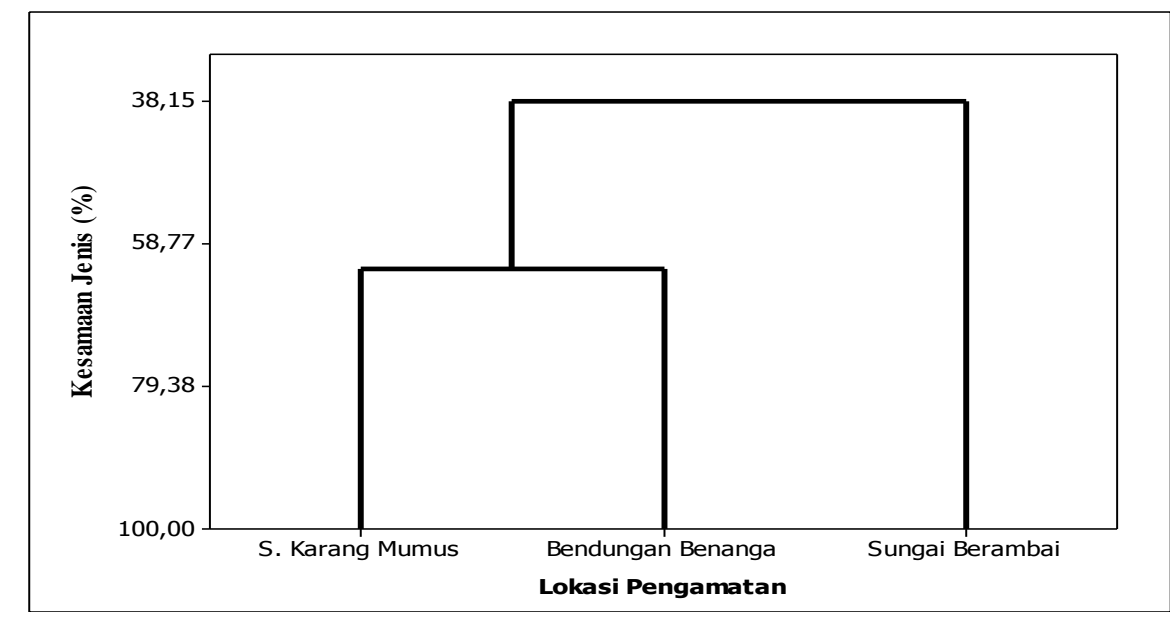

Gambar 23. Dendogram Cluster Analysis Antar Lokasi Penelitian Berdasarkan Kesamaan Spesies yang Terdapat di Bendungan Lempake, Sungai Karang Mumus dan Sungai Berambai

Cluster analysis ini merupakan analisis kondisi habitat berdasarkan kesamaan jenis pada setiap lokasi. Berdasarkan Gambar 23, hasil cluster analysis menunjukkan bahwa kawasan sungai Karang Mumus dan Bendungan Lempake berada dalam satu kelompok kondisi habitat yang sama sebesar $62,45 \%$, sedangkan kesamaan habitat Odonata di kawasan sungai Berambai terpisah dari kelompok sungai Karang Mumus dan Bendungan Lempake dengan nilai persentase 38,15\%. Dari hasil persentase ini dapat disimpulkan bahwa kondisi habitat sungai Karang Mumus dan Bendungan Lempake tidak berbeda jauh karena kedua kawasan ini merupakan kawasan perairan yang cukup besar dan terbuka serta terhubung dengan satu aliran sungai yang sama, oleh karena itu terdapat banyak spesies yang sama ditemukan dari kedua kawasan ini, sedangkan sungai Berambai memiliki perbedaan kondisi habitat dengan sungai Karang Mumus dan Bendungan Lempake karena kawasan ini merupakan kawasan perairan kecil yang ada di dalam hutan.

Data pada Tabel 3 dan Gambar 23 menjelaskan bahwa di kawasan Bendungan Lempake, sungai Karang Mumus dan sungai Berambai terdapat kesamaan jenis spesies Odonata (capung) dalam kategori sedang, Hal ini membuktikan masih adanya keanekaragaman spesies dari ketiga kawasan perairan tersebut, hal ini sesuai dengan yang dilaporkan Aswari et al. (2011). Faktor Abiotik Kawasan Perairan Bendungan Lempake, sungai Karang Mumus dan sungai Berambai. Data pada Tabel 4. Menunjukkan bahwa nilai pH air yang terdapat di ketiga kawasan perairan di atas tidak berbeda jauh, nilai rata-rata $\mathrm{pH}$ air di kawasan sungai Karang Mumus adalah 7,1; nilai rata-rata $\mathrm{pH}$ air di kawasan Bendungan Lempake adalah 7,0 dan rata-rata nilai pH air di kawasan sungai Berambai adalah 7,1. Amani \& Prawiroredjo (2016) menjelaskan bahwa derajat keasaman $(\mathrm{pH})$ merupakan salah satu faktor penting yang dapat mempengaruhi kehadiran dan keanekaragaman jenis Odonata (capung). Odonata (capung) menghabiskan hampir setengah dalam siklus hidupnya di perairan, sehingga jika pH dari perairan tersebut tidak optimal menunjang proses kehidupannya maka dia tidak akan ditemukan di sekitar perairan tersebut. Walaupun begitu, Sharma et al. (2007), menyatakan bahwa ada beberapa jenis Odonata (capung) yang memiliki toleransi tinggi yang tahan dengan kondisi perairan yang tidak optimal (tercemar) contohnya spesies Orthetrum sabina.

Selain $\mathrm{pH}$ faktor yang mempengaruhi kehadiran Odonata (capung) adalah suhu. Pada kawasan sungai Karang Mumus nilai rata-rata suhunya adalah $29,9^{\circ}$ dengan nilai rata-rata kelembaban relatif $87 \%$, pada kawasan Bendungan Lempake nilai suhunya adalah $31^{\circ}$ dengan nilai rata-rata kelembaban 
relatif $86 \%$ dan pada kawasan sungai Berambai nilai rata-rata suhunya adalah $28,2^{\circ}$ dengan nilai ratarata kelembaban relatif $90 \%$. Suhu lingkungan disemua lokasi masih termasuk ke dalam rentang suhu yang menunjang kehidupan capung. Menurut Dharmawan (2005), Odonata (capung) merupakan serangga yang termasuk dalam golongan hewan yang memperoleh panas dari lingkungan untuk menaikkan suhu tubuhnya, sehingga suhu lingkungan menentukan suhu tubuh capung. Suhu lingkungan yang mendukung aktivitas capung adalah minimal $150 \mathrm{C}$, optimal $250 \mathrm{C}$ dan maksimal 450 C. Jika suhu berada diluar suhu optimal tapi tidak ekstrim (diluar rentang suhu min-max) maka masih dapat ditoleransi oleh Odonata (capung). Metabolisme tubuh akan terbatas, sehingga aktivitas dan pergerakan dari Odonata (capung) akan berkurang. Suhu lingkungan menjadi faktor pembatas bagi aktivitas Odonata (capung), yakni mempengaruhi kebiasaan terbang dari Odonata (capung) dewasa.

\section{SIMPULAN}

Terdapat 22 spesies Odonata (capung) di ketiga lokasi (Bendungan Lempake, Sungai Karang Mumus dan Sungai Berambai) yang tergolong ke dalam 4 famili dan 2 subordo. Nilai Indeks Keanekaragaman $\left(H^{\prime}\right)$ kawasan perairan sungai Karang Mumus sebesar 2,52, kawasan perairan Bendungan Lempake sebesar 2,83 dan kawasan perairan sungai Berambai sebesar 2,53. Keanekaragaman Odonata (capung) di ketiga lokasi kawasan perairan ini masih termasuk dalam kategori sedang karena nilai $\mathrm{H}^{\prime}$ lebih dari 1,5 dan kurang dari 3,5. Hal ini menandakan bahwa kondisi lingkungan di ketiga kawasan perairan ini masih dapat mendukung kelangsungan hidup Odonata. Selanjutnya, untuk penelitian berikutnya sebaiknya dilakukan metode capture recapture agar tidak perlu lagi untuk mengkoleksi serangga.

\section{UCAPAN TERIMA KASIH}

Peneliti mengucapkan terima kasih kepada Kepala Laboratorium Ekologi dan Sistematika Hewan beserta staf atas fasilitas yang diberikan untuk melaksanakan penelitian. Selanjutnya, peneliti berterima kasih kepada teman-teman yang telah banyak membantu dalam pelaksanaan penelitian.

\section{RUJUKAN}

Amani, F. dan Prawiroredjo, K. (2016). Alat Ukur Kualitas Air Minum dengan Parameter Ph, Suhu, Tingkat Kekeruhan, dan Jumlah Padatan Terlarut. JETri, 14(1): 49-62. Retrieved from https://media.neliti.com/media/publications/70664-ID-alat-ukur-kualitas-air-minum-dengan-para.pdf

Aswari P., Noerdjito W. A., dan Peggie D. (2011). Capung di Kawasan Gunung Ciremai dalam Fauna Serangga Gunung Ciremai. Bogor: LIPI Press. Retrieved from http://lipi.go.id/publikasi/kupu-kupugunung-ciremai-dan-sekitarnya-dalam-fauna-serangga-gunung-ciremai-kumbang-sungut-panjangcapung-kupu-kupu/4689

Borror, D. J., Triplehorn, C. A. dan Johnson, N. F. (2008). Pengenalan Pelajaran Serangga, edisi VI. Yogyakarta: Gadjah Mada University Press. Retrieved from http://library.um.ac.id/freecontents/index.php/buku/detail/pengenalan-pelajaran-serangga-donald-j-borror-charles-a-triplehor n-norman-f-johnson-penerjemah-soetiyono-partosoedjono-27957.html

Bybee, S. (2018). Dragonflies and Damselflies. University of Florida. Retrieved from http://entnemdept. ufl.edu/creatures/misc/odonata/odonata.html

Dalzochio, M. S., Costa, J. M and Uchôa M.A. (2011). Diversity of Odonata (Insecta) in lotic systems from Serra da Bodoquena, Mato Grosso do Sul State, Brazil. Revista Brasileira de Entomologia, 55 (1): http://dx.doi.org/10.1590/S0085-56262011000100014

Dharmawan, A., Ibrohim, Tuarita. H., Suwono, H. dan Susanto, P. (2005). Ekologi Hewan. Malang: Universitas Negeri Malang. Retrieved from http://library.um.ac.id/free-contents/index.php/buku/ 
detail/ekologi-hewan-oleh-agus-dharmawan-et-al-29096.html

Dwari, S., A. Patra, A. K. Mondal. (2018). First report of Libellago lineata (Burmeister, 1839) from South West Bengal, India. International Journal of Entomology Research. 3 (5): Retrieved from https://www.researchgate.net/publication/328265979

Feriwibisono, B. (2011). Peran Capung Sebagai Predator. Retrieved from http://indonesia dragonfly.org/peran-capung-sebagai-predator/

Gullan, P. J. and P. S. Cranston. (2010). The Insect, an Outline of Entomoloagy. UK: Willey Blackwell. Retrieved from https://www. wiley.com/en-us/The+Insects\%3A+An+Outline+of+Entomology\%2C+ 4th+Edition-p-9781444317671

Hamalainen, M., dan Karube, H. (2001). Rhinocypha orea spec. nov. a new damselfly from Vietnam (Odonata: Chlorocyphidae). Zoologische Mededelingen: Vietnam. Retrieved from https://www. researchgate.net/publication/254893905

Kalkman, V. J. dan Dingemanse, N. J. (2008). Global Diversity of Dragonflies (Odonata) in Freshwater. Freshwater Animal Diversity Assessment. 351-363. Retrieved from https://link.springer.com/ chapter/10.1007/978-1-4020-8259-7_38

Krebs, C. J. (1989). Ecological Methodology. Addison-Wesley Educational Publishers. Retrieved from https://books.google.co.id/books/about/Ecological_Methodology.html?id=1GwVAQAAIAAJ\&redir_ esc $=y$

Magurran, A. E. (1998). Ecological Diversity and Its Measurement. Princeton, NJ Princeton University Press. Retrieved from https://press.princeton.edu/books/paperback/9780691084916/ecologicaldiversity-and-its-measurement

Munroe, K. (2012). Dragonfly of N. Va: Clubtail Family - Gomphidae. Retrieved from http://www. dragonfliesnva.com/

Moore, W. N. (2001). Conservation In Dragonflies of the World. Washington DC: Smithsonian institution Press. Retrieved from https://books.google.co.id/books/about/Dragonflies_of_the_World.mhtml?id $=d d z w J i u R P 48 C \&$ redir_esc $=y$

Morse, J. C. (2009). Insect Biodiversity: Science and Society (Editor: Robert G. Foottit and Peter H. Adler). Malden: Blackwell Publishing Ltd. Retrieved from https://www.wiley.com/en-us/Insect +Biodiversity\%3A+Science+and+Society-p-9781444308228

Muriyani, H. dan Susetiawan. (2002). Kohesi Sosial Dan Kelangsungan Hidup: Studi Pada Pemukiman Transmigrasi Joyomulyo Yang Mengalami Musibah Akibat Pembangunan Bendungan Benanga Di Kelurahan Lempake, Kec. Samarinda Utara, Kota Samarinda. Yogyakarta: Gajah Mada University Press. Retrieved from https://repository.ugm.ac.id/58506/

Nugrahani, M.P., Nazar, L., Makitan dan T., Setiyono. (2014). Peluit Tanda Bahaya, Capung Indikator Lingkungan, Panduan Penilaian Kualitas Lingkungan Melalui Capung. Yogyakarta: Indonesia Dragonfly Society.

Portal Resmi Pemerintah Kota Samarinda. (2012). Kondisi Geografis Kota Samarinda. Retrieved from https://www.samarindakota.go.id/website/laman/kondisi-geografis

Odum, E. P. (2005). Fundamentals of Ecology.12th.ed. Cengace Learning Press. Singapore.

Ridwan, P. Sudira, S. Susanto dan L. Sutiarso. (2013). Manajemen Sumberdaya Air Daerah Aliran Sungai Sekampung di Antara Bendungan Batutegi dan Bendung Argoguruh, Propinsi Lampung: Kerangka Analitis Penyusunan Pola Operasional Waduk Harian. Agritech, 33 (2); 226-233. https://doi.org/10.22146/agritech.9801

Setiyono, J., S. Diniarsih, E. N R. Oscilata dan N. S Budi. (2017). Dragonflies of Yoyakarta Jenis Capung Daerah Istimewa Yogyakarta. Yogyakarta: Indonesia Dragonfly Society. Retrieved from https://drive.google.com/drive/u/0/my-drive

Sharma, G., R. Sundararaj and L.R Karibaskaraja. (2007). Species Diversity of Odonata in the Selected Provenances of Sandal in Southern India. Zoos' Print Journal. 22(7): 2765-2767. Retrieved from https://www.researchgate.net/publication/286711966

Silsby, J. (2001). Dragonflies of the World. The Natural History Museum in association with CSIRO 
Publising: United Kingdom. Retrieved from https://books.google.co.id/books/about/Dragonflies _of_the_World.html?id=ddzwJiuRP48C\&redir_esc=y

Subagyo, T. S. (2016). Keanekaragaman Capung (Odonata) di Kawasan Rawa Jombor, Klaten, Jawa Tengah. Yogyakarta: UNY. Retrieved from https://eprints.uny.ac.id/49001/

Suharni, S.S. (1991). Kunci Determinasi Serangga. Yogyakarta: Kanisius. Retrieved from https://opac. perpusnas.go.id/DetailOpac.aspx?id=667516

Tjokrokusumo, S.W. (2006). Bentik Makroinvertebrata Sebagai Bioindikator Polusi Lahan Perairan. Jurnal Hidrosfir. 1 (1): 8-20. Retrieved from http://ejurnal.bppt.go.id/index.php/JHI/article/view/627

UCMP. (2020). Dragonflies and Damselflies. Retrieved from https://ucmp.berkeley.edu/arthropoda/ uniramia/odonatoida.html

Wakhid, R. Koneri.,T. Tallei., \& Maabuat, Pience V. (2014). Kelimpahan Populasi Capung Jarum (Zygoptera) di Kawasan Taman Nasional Bogani Nani Wartabone, Sulawesi Utara. Jurnal Bioslogos, 4 (2). Retrieved from https://ejournal.unsrat.ac.id/index.php/bioslogos/article/view/5234

Wahyuni, M. (2017). Variasi Dosis Biji Kelor (Moringa Seed) Dalam Menurunkan Kekeruhan (Turbidity) Air Bersih Yang Digunakan Oleh Masyarakat Di Sungai Karang Mumus Kota Samarinda. Jurnal IImiah Sehat Bebaya, 1 (1). Retrieved from https://adoc.pub/jurnal-ilmiah-sehat-bebaya-vol1-no-1januari-2017.html

WfHC. (2020). Terrestrial Biodiversity. Retrieved from https://www.anbg.gov.au/cpbr/WfHC/index.html 